Original Paper http://ajol.info/index.php/ijbcs http://indexmedicus.afro.who.int

\title{
Theoretical study of the structure and acidity of condensed tannin monomers
}

\author{
Benjamine Amon ASSOMA, Lucie Affoué BEDE, Kicho Denis YAPO*, \\ Boka Robert N'GUESSAN and Martial Venance SAY
}

\author{
Laboratoire de Chimie Organique et de Substances Naturelles, UFR-SSMT, Université Felix Houphouët \\ Boigny de Cocody; 22 BP 582 Abidjan 22, Côte-d'Ivoire. \\ *Corresponding author; E-mail: yapokicho@gmail.com; Tel: +225 49790419
}

\begin{abstract}
Low level of polyphenols absorption is due among other things to the formation of irreversible complexes between non-heminic iron $\left(\mathrm{Fe}^{2+}, \mathrm{Fe}^{3+}\right)$ and these polyphenols through their hydroxyl groups. Understanding of these complexes formation mechanisms led us to explore hydroxyl groups acidity of these polyphenols monomers (catechin, epicatechin, gallocatechin and epigallocatechin) mainly found in food. Quantum chemistry modelling, more precisely the functional density theory (DFT) method, associated to 6$311 \mathrm{G}(\mathrm{d}, \mathrm{p})$ base was used in gas phase. Spectroscopic, thermodynamic descriptors and geometric parameters resulting from calculations showed a slight stability of catechin compared to epicatechin and gallocatechin compared to epigallocatechin. As for the acidity of these monomers hydroxyl groups, the results show that it decreases similarly as follows: $\mathrm{O}_{4},>\mathrm{O}_{5}>\mathrm{O}_{7}>\mathrm{O}_{5},>\mathrm{O}_{3}$ for Catechin and epicatechin; $\mathrm{O}_{3},>\mathrm{O}_{5}>\mathrm{O}_{4},>\mathrm{O}_{7}>\mathrm{O}_{5}$, $>\mathrm{O}_{3}$ and $\mathrm{O}_{3},>\mathrm{O}_{4}>\mathrm{O}_{5}>\mathrm{O}_{7}>\mathrm{O}_{5}>\mathrm{O}_{3}$ respectively for gallocatechin and epigallocatechin.

(C) 2018 International Formulae Group. All rights reserved.
\end{abstract}

Keywords: Catechin, Epicatechin, Gallocatechin, Epigallocatechin, Acidity, DFT.

\section{INTRODUCTION}

Catechin, epicatechin, gallocatechin and epigallocatechin are condensed tannins monomer found in abundance in human nutrition. They are found in fruits and vegetables but also in chocolate and wine. Their study got a great interest since they had not only anticancer properties but also cardiovascular effects (Rein et al., 2000; Martin and Andriantsitohaina, 2002; Raju et al., 2014). In addition, they are used in the prevention of ulcers and hormone-dependent diseases (Funatogawa et al., 2004; Ruggiero et al., 2006; Gerber and Berta, 2006; Lainé et al., 2007). Several scientific studies have shown that inorganic or non-heminic iron $\left(\mathrm{Fe}^{2+}, \mathrm{Fe}^{3+}\right)$ inhibits intestinal absorption of condensed tannins from food by formation of insoluble and irreversible complexes. (Roberta et al., 2002; Seigo et al., 2002; Scalbert et al., 2002; Jeremy, 2003; Mourad et al., 2007). It's established that this phenomenon occurs between phenolic hydroxyls of tannins and inorganic iron (Tapiero H. et al., 2002; Manach C. et al., 2004). Any solution aimed at avoiding formation of these complexes in order to optimize absorption of tannins requires first, precise knowledge of mechanisms of action. However, process of complex formation between condensed tannins and inorganic iron is not yet clearly established. Knowing that hydroxyl groups of 
tannins are the sites of non heminic iron binding, our objective during this work is to study preferential sites at these hydroxyl groups. This, by theoretical determination of these hydroxyl groups acidity of monomers (catechin, epicatechin, gallocatechin and epigallocatechin). Theoretical calculations of quantum chemistry using functional density theory (DFT) method, associated to $6-311 \mathrm{G}$ $(d, p)$ base allowed us to carry out this study.

\section{MATERIALS AND METHODS}

The Acer predator processor runs the calculations. Catechin, epicatechin, gallocatechin and epigallocatechin molecules (Figure 1) were drawn by GaussView 5.0 software (Frisch et al. 2003). Calculations were made in gas phase using the functional density theory method (DFT) with functional hybrid B3lyp, associated to 6-311G (d,p) base, incorporated in the GAUSSIAN-03 program (Frisch et al., 2003). Initial geometries have been optimised. Gibbs free energies $(\mathrm{G})$ are obtained from frequencies calculation.

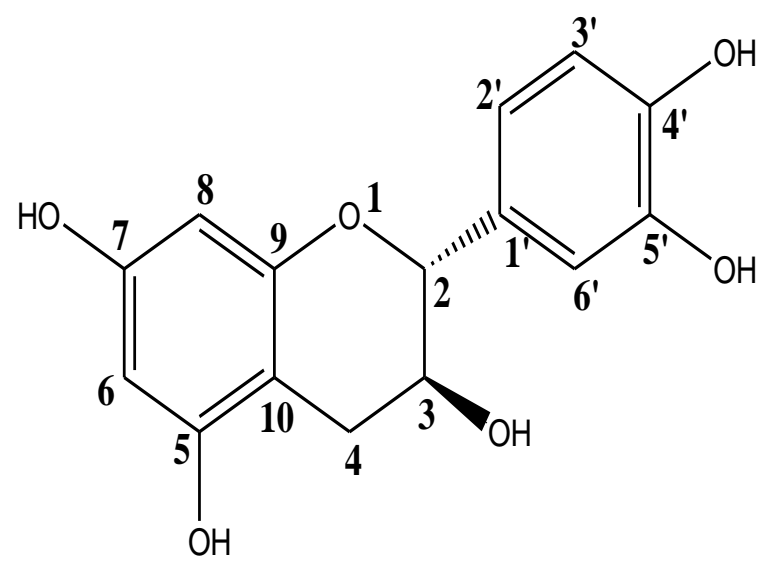

Catechin

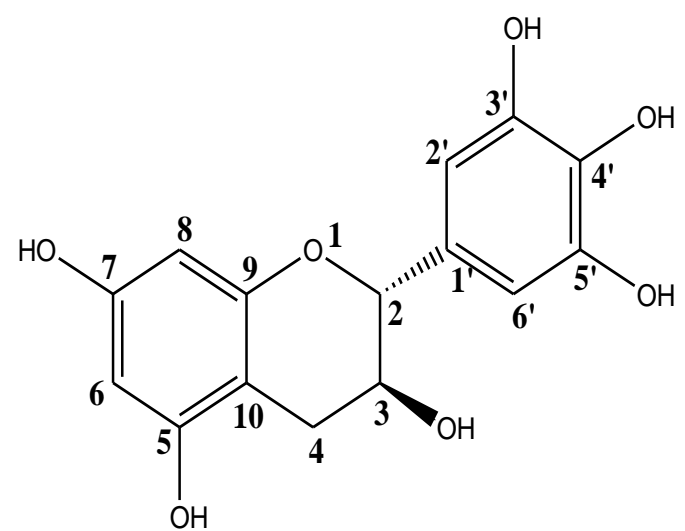

Gallocatechin<smiles>Oc1cc(O)c2c(c1)O[C@H](c1ccc(O)c(O)c1)[C@H](O)C2</smiles>

Epicatechin<smiles>Oc1cc(O)c2c(c1)O[C@H](c1cc(O)c(O)c(O)c1)[C@H](O)C2</smiles>

Epigallocatechin

Figure 1: structures of catechin, epicatechin, gallocatechin and epigallocatechin. 


\section{RESULTS}

\section{Geometric parameters}

Figure 1 shows the structures of catechin, epicatechin, gallocatechin and epigallocatechin. Bond lengths and measured dihedral angles are contained in Table 1. C-O bond lengths of catechin derivatives varied very little compared to those of epicatechin. Dihedral angle $\mathrm{O}_{1}-\mathrm{C}_{2}-\mathrm{C}_{1^{\prime}}-\mathrm{C}_{6}$ ' is smaller in epicatechin compared to catechin. It's also smaller in epigallocatechin compared to gallocatechin. Same remarks are made at the dihedral angle $\mathrm{O}_{1}-\mathrm{C}_{2}-\mathrm{C}_{1}-\mathrm{C}_{2}$.

\section{Theoretical frequencies}

Catechin and epicatechin are composed of 35 atoms, they have $(3 N-6=99)$ normal modes of vibration. Gallocatechin and epigallocatechin had 36 atoms which gave 102 normal modes of vibration. We are particularly interested in $\mathrm{vO}-\mathrm{H}$ elongations because oxygen atoms are preferred sites for complexation with iron. Values are contained in Tables 2 and 3 . In general, $v \mathrm{O}-\mathrm{H}$ elongations range from $3786 \mathrm{~cm}^{-1}$ to 3850 $\mathrm{cm}^{-1}$.

\section{Stability}

Gibbs energy (G), at computational level B3LYP / 6-311G (d, p), helps to discuss relative stability of catechin and its derivatives. Table 4 summarises its values; $\Delta \mathrm{G}$ is difference between Gibbs energy of catechin and epicatechin on one hand and on other hand between gallocatechin and epigallocatechin. The data in Table 4 show relative stability of catechin and gallocatechin compared to epicatechin and epigallocatechin, respectively.

\section{Acidity}

Catechin, epicatechin, gallocatechin and epigallocatechin have hydrogenated sites (hydroxyl groups) which may be deprotonated. Choice of the site of deprotonation depends of strength of acid. $\Delta \mathrm{G}$ variation of associated reaction $\left(\mathrm{AH} \rightarrow \mathrm{A}^{-}+\right.$ $\mathrm{H}^{+}$) helps to evaluate acidity of oxygen atoms of catechin and its derivatives (Remko, 2003):

$\Delta \mathrm{G}=\Delta \mathrm{H}-\mathrm{T} \Delta \mathrm{S}$

$\Delta \mathrm{G}=\mathrm{G}\left(\mathrm{A}^{-}\right)+\mathrm{G}\left(\mathrm{H}^{+}\right)-\mathrm{G}(\mathrm{AH})$

$\mathrm{G}\left(\mathrm{H}^{+}\right)=2,5 \mathrm{RT}-\mathrm{TS}^{\circ}\left(\mathrm{H}^{+}\right)=1,48-7,76=$ $-628 \mathrm{Kcal} . \mathrm{mol}^{-1}$ in gas phase

With: AH: acid molecule; $\mathbf{A}^{-}$: deprotonated molecule; G: Gibbs energy or free enthalpy reaction; $\Delta \mathbf{G}$ : variation of free enthalpy reaction; $\mathbf{T}$ : temperature; $\mathbf{R}$ : perfects gas constant; $\mathbf{S}^{\circ}$ : standard entropy reaction; $\Delta \mathbf{S}$ : variation of entropy reaction.

Table 1: Bond lengths $(\AA)$ and dihedral angles $\left({ }^{\circ}\right)$.

\begin{tabular}{lcccc}
\hline $\begin{array}{c}\text { Geometric } \\
\text { parameters }\end{array}$ & Catechin & Epicatechin & Gallocatechin & Epigallocatechin \\
\hline $\mathrm{O}_{1}-\mathrm{C}_{2}$ & 1,44 & 1,44 & 1,44 & 1,44 \\
$\mathrm{O}_{1}-\mathrm{C}_{9}$ & 1,37 & 1,37 & 1,37 & 1,37 \\
$\mathrm{O}_{3}-\mathrm{C}_{3}$ & 1,42 & 1,42 & 1,42 & 1,42 \\
$\mathrm{O}_{5}-\mathrm{C}_{5}$ & 1,37 & 1,37 & 1,37 & 1,37 \\
$\mathrm{O}_{7^{-}}-\mathrm{C}_{7}$ & 1,36 & 1,37 & 1,36 & 1,37 \\
$\mathrm{O}_{3}-\mathrm{C}_{3^{\prime}}$ & - & - & 1,38 & 1,37 \\
$\mathrm{O}_{4^{\prime}}-\mathrm{C}_{4^{\prime}}$ & 1,38 & 1,38 & 1,37 & 1,37 \\
$\mathrm{O}_{5^{\prime}}-\mathrm{C}_{5^{\prime}}$ & 1,36 & 1,36 & 1,36 & 1,36 \\
$\mathrm{C}_{2}-\mathrm{C}_{1^{\prime}}$ & 1,52 & 1,52 & 1,52 & 1,52 \\
$\mathrm{O}_{1}-\mathrm{C}_{2}-\mathrm{C}_{1^{\prime}}-\mathrm{C}_{6^{\prime}}$ & 166,08 & 155,46 & 166,5 & 154,12 \\
$\mathrm{O}_{1}-\mathrm{C}_{2}-\mathrm{C}_{1^{\prime}}-\mathrm{C}_{2}$ & $-13,22$ & $-24,50$ & $-12,87$ & $-26,09$ \\
\hline
\end{tabular}


Table 2: IR Frequencies $\left(\mathrm{cm}^{-1}\right)$ and Intensities of O-H Elongations of Catechin and Epicatechin.

\begin{tabular}{lcccc}
\hline Elongations O-H & \multicolumn{2}{c}{ Catechin } & \multicolumn{2}{c}{ Epicatechin } \\
& Frequency & IR intensity & Frequency & IR intensity \\
\hline $\mathrm{vO}_{3}-\mathrm{H}$ & 3808 & 30 & 3797 & 26 \\
$\mathrm{vO}_{5}-\mathrm{H}$ & 3836 & 67 & 3835 & 66 \\
$\mathrm{vO}_{7}-\mathrm{H}$ & 3833 & 65 & 3833 & 64 \\
$\mathrm{vO}_{4}-\mathrm{H}$ & 3850 & 83 & 3850 & 84 \\
$\mathrm{vO}_{5}-\mathrm{H}$ & 3789 & 114 & 3789 & 117 \\
\hline
\end{tabular}

Table 3: IR Frequencies $\left(\mathrm{cm}^{-1}\right)$ and Intensities of O-H elongations of gallocatechin and epigallocatechin.

\begin{tabular}{lcccc}
\hline O-H Elongations & \multicolumn{2}{c}{ Gallocatechin } & \multicolumn{2}{c}{ Epigallocatechin } \\
& Frequency & IR intensity & Frequency & IR intensity \\
\hline $\mathrm{vO}_{3}-\mathrm{H}$ & 3808 & 29 & 3788 & 20 \\
$\mathrm{vO}_{5}-\mathrm{H}$ & 3836 & 68 & 3836 & 68 \\
$\mathrm{vO}_{7}-\mathrm{H}$ & 3833 & 65 & 3833 & 65 \\
$\mathrm{vO}_{3}-\mathrm{H}$ & 3848 & 66 & 3846 & 67 \\
$\mathrm{vO}_{4}-\mathrm{H}$ & 3806 & 108 & 3805 & 108 \\
$\mathrm{vO}_{5}-\mathrm{H}$ & 3787 & 112 & 3786 & 131 \\
\hline
\end{tabular}

Table 4: Gibbs energies of catechin and its derivatives.

\begin{tabular}{lcc}
\hline \multicolumn{1}{c}{ Compounds } & $\mathbf{G}(\mathbf{a . u})$ & $\boldsymbol{\Delta G}\left(\mathrm{Kcal}_{\mathbf{~ m o l}}{ }^{\mathbf{1}}\right)$ \\
\hline Catechin & $-1031,404$ & 0 \\
Epicatechin & $-1031,403$ & 0,628 \\
Gallocatechin & $-1106,64581$ & 0 \\
Epigallocatechin & $-1106,64478$ & 0,646 \\
\hline
\end{tabular}

(a.u): atomic unit; 1 a.u $=627,51 \mathrm{kcal} / \mathrm{mol}$. 
Table 5: Acidity of Catechin and Epicatechin.

\begin{tabular}{|c|c|c|}
\hline Compounds & G (a.u) & $\Delta G\left(\mathrm{Kj} \cdot \mathrm{mol}^{-1}\right)$ \\
\hline Catechin & $-1031,404$ & \\
\hline Catechin $\left(\mathrm{O}_{3}\right.$-anion $)$ & $-1030,814$ & 1548,8 \\
\hline Catechin $\left(\mathrm{O}_{5}\right.$-anion $)$ & $-1030,857$ & 1435,9 \\
\hline Catechin $\left(\mathrm{O}_{7}\right.$-anion $)$ & $-1030,853$ & 1446,3 \\
\hline Catechin $\left(\mathrm{O}_{\left.4^{\prime} \text {-anion }\right)}\right.$ & $-1030,868$ & 1407,0 \\
\hline Catechin $\left(\mathrm{O}_{5}\right.$-anion $)$ & $-1030,846$ & 1464,8 \\
\hline Epicatechin & $-1031,403$ & \\
\hline Epicatechin $\left(\mathrm{O}_{3}\right.$-anion $)$ & $-1030,821$ & 1527,8 \\
\hline Epicatechin $\left(\mathrm{O}_{5}\right.$-anion $)$ & $-1030,854$ & 1442,8 \\
\hline Epicatechin $\left(\mathrm{O}_{7}\right.$-anion $)$ & $-1030,850$ & 1451,6 \\
\hline Epicatechin $\left(\mathrm{O}_{4^{\prime}}\right.$-anion $)$ & $-1030,870$ & 1399,1 \\
\hline Epicatechin $\left(\mathrm{O}_{5}\right.$-anion $)$ & $-1030,849$ & 1454,3 \\
\hline
\end{tabular}

Table 6: Acidity of gallocatechin and epigallocatechin.

\begin{tabular}{|c|c|c|}
\hline Compounds & G (au) & $\Delta G(\mathrm{Kj} / \mathrm{mol})$ \\
\hline Gallocatechin & $-1106,646$ & \\
\hline Gallocatechin $\left(\mathrm{O}_{3}\right.$-anion $)$ & $-1106,057$ & 1546,1 \\
\hline Gallocatechin $\left(\mathrm{O}_{5}\right.$-anion $)$ & $-1106,102$ & 1428,0 \\
\hline Gallocatechin $\left(\mathrm{O}_{7}\right.$-anion $)$ & $-1106,098$ & 1438,5 \\
\hline Gallocatechin $\left(\mathrm{O}_{3 \text {-anion })}\right.$ & $-1106,109$ & 1409,6 \\
\hline Gallocatechin $\left(\mathrm{O}_{4^{-}}\right.$-anion $)$ & $-1106,100$ & 1433,3 \\
\hline Gallocatechin $\left(\mathrm{O}_{\left.5^{\prime} \text {-anion }\right)}\right.$ & $-1106,087$ & 1467,4 \\
\hline Epigallocatechin & $-1106,645$ & \\
\hline Epigallocatechin $\left(\mathrm{O}_{3}\right.$-anion $)$ & $-1106,063$ & 1527,8 \\
\hline Epigallocatechin $\left(\mathrm{O}_{5}\right.$-anion $)$ & $-1106,099$ & 1433,3 \\
\hline Epigallocatechin $\left(\mathrm{O}_{7}\right.$-anion $)$ & $-1106,095$ & 1443,8 \\
\hline Epigallocatechin $\left(\mathrm{O}_{\left.3^{\prime} \text {-anion }\right)}\right.$ & $-1106,112$ & 1399,1 \\
\hline Epigallocatechin $\left(\mathrm{O}_{4}\right.$-anion $)$ & $-1106,103$ & 1422,8 \\
\hline Epigallocatechin $\left(\mathrm{O}_{5^{\prime}}\right.$-anion $)$ & $-1106,091$ & 1454,3 \\
\hline
\end{tabular}

(a.u): atomic unit; 1 u.a $=2625 \mathrm{kj} / \mathrm{mol}$ 


\section{DISCUSSION}

Catéchines, epicatechin, gallocatechin and epigallocatechin have different geometric parameters. In fact, the $\mathrm{C}_{7}-\mathrm{O}_{7}$ bond is $1,36 \AA$ in catechin and gallocatechin. It is $0,01 \AA$ longer in epicatechin and epigallocatechin. This difference is explained by fact that the $\mathrm{O}_{3}-\mathrm{H}$ bond is in front of plane in catechin and in gallocatechin and behind plane in epicatechin and in epigallocatechin. C4'-O4' bond is $1,38 \AA$ in catechin and epicatechin. It is $0,01 \AA$ shorter in gallocatechin and epigallocatechin. This inequality is due to presence of hydroxyl group $\mathrm{O}_{3}{ }^{\prime}-\mathrm{H}$ in gallocatechin and in epigallocatechin. Dihedral angle O1-C2-C1'-C6' is $166,08^{\circ}$ in catechin and is 10,62 smaller in epicatechin. It is $166,5^{\circ}$ in gallocatechin and is 11.96 smaller in epigallocatechin. Dihedral angle $\mathrm{O} 1-\mathrm{C} 2-\mathrm{C} 1^{\prime}-\mathrm{C} 2$ ' is $-13,22{ }^{\circ}$ in catechin and is 11,28 smaller in epicatechin. It is $-12,87^{\circ}$ in gallocatechin and is 13,22 smaller in epigallocatechin. Orientation of the $\mathrm{O}_{3}-\mathrm{H}$ bond thus influences the value of the dihedral angles (Ana et al., 2006; Hong et al., 2018).

$\mathrm{O}-\mathrm{H}(\mathrm{vO}-\mathrm{H})$ elongations of catechin and its derivatives appear between $3786 \mathrm{~cm}^{-1}$ and $3850 \mathrm{~cm}^{-1}$. The $v \mathrm{O}_{4}{ }^{\prime}-\mathrm{H}$ elongation is observed at $3850 \mathrm{~cm}^{-1}$ in catechin and epicatechin, at $3806 \mathrm{~cm}^{-1}$ in gallocatechin and at $3805 \mathrm{~cm}^{-1}$ in epigallocatechin. This difference is explained by the presence of the hydroxyl group $\mathrm{O}_{3^{\prime}}-\mathrm{H}$ in gallocatechin and in epigallocatechin. $\quad\left(\mathrm{vO}_{5}-\mathrm{H}\right)$ elongation is virtually identical in the four compounds. It comes out at $3836 \mathrm{~cm}^{-1}$ in catechin, gallocatechin and epigallocatechin and at $3835 \mathrm{~cm}^{-1}$ in epicatechin. $\mathrm{vO}_{7}-\mathrm{H}$ elongation appears at $3833 \mathrm{~cm}^{-1}$ in the four compound. $v \mathrm{O}_{3}-\mathrm{H}$ elongation is least intense. It appears at $3808 \mathrm{~cm}^{-1}$ in catechin and gallocatechin, at $3797 \mathrm{~cm}^{-1}$ in epicatechin and at $3788 \mathrm{~cm}^{-1}$ in epigallocatechin (Jayshree et al., 2010).

Difference between the frequencies of catechin and epicatechin on one hand and gallocatechin and epigallocatechin on other hand is certainly due to fact that $\mathrm{O}_{3}-\mathrm{H}$ bond is in front of or behind plane. Elongation $\mathrm{vO}_{5^{\prime}} \mathrm{H}$ is most intense. It was released at $3789 \mathrm{~cm}^{-1}$ in catechin and epicatechin, at $3787 \mathrm{~cm}^{-1}$ in gallocatechin and $3786 \mathrm{~cm}^{-1}$ in epigallocatechin.

With regard to stability, results in Table 4 show that catechin is more stable than epicatechin with an energy difference of 0.628 $\mathrm{Kcal} / \mathrm{mol}$; similarly, gallocatechin is more stable than epigallocatechin with an energy difference of $0.646 \mathrm{Kcal} / \mathrm{mol}$.

Acid nature of oxygen atoms of catechin and its derivatives is related to the $\Delta \mathrm{G}$ value. Lower it is, more oxygen in the position is acid. Under these conditions, $\mathrm{O}_{4}$ ' oxygen atom is most acid site of catechin, followed by $\mathrm{O}_{5}$ oxygen atom. Oxygen atom $\mathrm{O}_{4}$ ' is also most acid site of epicatechin. Definitively, in catechin and epicatechin acidity of oxygen atoms varies in same direction. The descending order is $\mathrm{O}_{4^{\prime}}>\mathrm{O}_{5}>$ $\mathrm{O}_{7}>\mathrm{O}_{5}>\mathrm{O}_{3}$. The oxygen atom $\mathrm{O}_{3}$, is most acid site of gallocatechin, then oxygen $\mathrm{O}_{5}$, after oxygen $\mathrm{O}_{4}$. In general, in gallocatechin, the acidity of oxygen atoms decreases in order $\mathrm{O}_{3^{\prime}}>\mathrm{O}_{5}>\mathrm{O}_{4^{\prime}}>\mathrm{O}_{7}>\mathrm{O}_{5^{\prime}}>\mathrm{O}_{3}$. Oxygen $\mathrm{O}_{3^{\prime}}$ is also most acid site of epigallocatechin, followed by oxygen $\mathrm{O}_{4}{ }^{\prime}$. Decreasing order of epigallocatechin acidity oxygen atoms is $\mathrm{O}_{3^{\prime}}$ > $\mathrm{O}_{4^{\prime}}>\mathrm{O}_{5}>\mathrm{O}_{7}>\mathrm{O}_{5^{\prime}}>\mathrm{O}_{3}$. The oxygen atom $\mathrm{O}_{3}$ is thus least acid site of catechin and its derivatives (Ana et al., 2006; Jayshree et al., 2010; Hong et al., 2018).

\section{Conclusion}

The acidity of catechin and epicatechin decreased in the order $\mathrm{O}_{4}>\mathrm{O}_{5}>\mathrm{O}_{7}>\mathrm{O}_{5}>\mathrm{O}_{3}$ while that of gallocatechin and epigallocatechin decreased in the order $\mathrm{O}_{3},>$ $\mathrm{O}_{5}>\mathrm{O}_{4}>\mathrm{O}_{7}>\mathrm{O}_{5}>\mathrm{O}_{3}$ and $\mathrm{O}_{3},>\mathrm{O}_{4^{\prime}}>\mathrm{O}_{5}>$ $\mathrm{O}_{7}>\mathrm{O}_{5}>\mathrm{O}_{3}$. Knowing the theoretical acidity order of the different hydroxyl groups of the monomers, we will focus our researches to modelize different models of polyphenol inorganic iron complexes likely to be formed in the human organism according to these results. In a second step, complexation sites of inorganic iron will also be modelized to possibly reduce affinity of these condensed tannins with respect to iron. 


\section{COMPETING INTERESTS}

The authors declare that there are no competing interests.

\section{AUTHORS' CONTRIBUTIONS}

Bioinformatics calculations were carried out by KDY, BAA and LAB. Results interpretation was done by KDY, BAA and BRN. Finally, manuscript writing was done by KDY, BAA and MVS.

\section{ACKNOWLEDGEMENTS}

Thanks to the colleagues of Organic Chemistry and Natural Substances laboratory of Felix Houphouët Boigny University for their advice.

\section{REFERENCES}

Ana MM, Wilson DG, Mitnik. 2006. Theoretical study of the molecular properties and chemical reactivity of (+)catechin and (-)-epicatechin related to their antioxidant ability. Journal of Molecular Structure: THEOCHEM., 761(1-3): 97-106.

Frisch Mr J, Trucks GW, Schlege L HB, Scuseria GE, Robb Mr A, Cheeseman JR, Montgomery JA Jr, Vreven T, Kudin KNR., Burant JC, Millam JMr, Iyengar SS, Tomasi J, Baroness V, Mennucci B, Cossi Mr, Scalmani G, Rega NR, Petersson GA, Nakatsuji H, Hada Mr, Ehara Mr, Toyota K, Fukuda R, Hasegawa J, Ishida Mr, Nakajima T, Honda Y, Kitao O, Nakai H., Klene Mr, Li X, Knox JE, Hratchian HP JB, Crosscountry race, Adamo C, Jaramillo J, Gomperts R, Stratmann RE, Yazyev O, Austin AJ, Cammi R, Pomelli C, Ochterski JW, Ayala PY, Morokuma K, Voth GA, Salvador PEIJJ, DannenbergVG, Zakrzewski, Dapprich S, Daniels AD, Strain MrC, Farkas O, Malick DK, Rabuck AD, Raghavachari K, Foresman JB, Ortiz JV, Cui Q, Baboul AG, Clifford S, Cioslowski J, Stefanov BB, Liu G, Liashenko A, Piskorz P, Komaromi I, Martin RL., Fox DJ, Keith T, Al-Laham MrA, Peng CY,
Nanayakkara A, Challacombe Mr, Token Entry Gill W, Johnson B, Chen W, Wong $\mathrm{Mr}$ W, Gonzalez C, Pople JA. 2003. Gaussian 03, Revision B.05. Gaussian, Inc., Pittsburgh Pa.

Funatogawa K, Hayashi S, Shimomura H, Yoshida T, Hatano T, Ito H, Hirai Y. 2004. Antibacterial activity of hydrolyzable tannins derived from medicinal plants against Helicobacter pylori. Microbiol. Immunol., 48(4): 251261.

Gerber M, Berta VI. 2006. Soja et phytoestrogènes. Arch. Pédiatrie, 13(6): 534-536. Hong Y, Xuejia X, Huan L, Siti NA, Su CTC, Seng PO, Edmund FT. 2018. The relative antioxidant activity and steric structure of green tea catechins - A kinetic approach. Food Chemistry, 257: 399-405.

Jayshree KK, Rahul VP, Vivekanand G, Shridhar G. 2010. Electronic Structure and Normal Vibrations in (+)-Catechin and $(-)$-Epicatechin Encapsulated $\beta$ Cyclodextrin. The Journal of Physical Chemistry A, 114(29): 7725-7732.

Jeremy PES. 2003. Metabolism of Tea Flavonoids in the Gastrointestinal Tract. American Society for Nutritional Sciences, 133(10): 3255S-3261S.

Lainé E, Hano C, Lamblin F. 2007. Les lignanes phyto-oestrogènes du lin sontils des bienfaiteurs méconnus? Phytothér., 5: 121-128.

Manach C, Scalbert A, Morand C, Remesy C, Jimenez L. 2004. Polyphenols: food sources and bioavailability. Am. J. Clin. Nut., 79: 727-747.

Martin S, Andriantsitohaina R. 2002. Cellular mechanism of vasculo-protection induced by polyphenols on the endothelium. Ann. Cardiol. Angéiol., 51(6): 304-315.

Mourad E, Charlotte C, Franck M, Hassan T. 2007. Complexation of iron (III) by catecholate-type polyphenols. Inorganica Chimica Acta, 360: 353-359.

Raju VSSG, Nareshraju N, Kannababu S, Gottumukkala VS. 2014. Determination 
of Catechin and Epicatechin Content in Chocolates by High-Performance Liquid Chromatography. International Scholarly Research Notices, 2014: 5 pages.

Rein D, Paglieroni TG, Wun T, Pearson DA, Schmitz HH, Gosselin R, Keen CL. 2000. Cocoa inhibits platelets activation and function. Am. J. Clin. Nutr., 72: 3035 .

Remko M. 2003. Theoretical Study of Molecular Structure and Gas-Phase Acidity of Some Biologically Active Sulfonamides. J. Phys. Chem. A, 107: 720-725.

Roberta RH, Sheryl AL, Cameron MS, Qin YZ, Derek DS, John FH, Cesar GF, Harold HS, Carl LK. 2002. Procyanidin dimer B2 [epicatechin- $(4 \beta-8)$ epicatechin] in human plasma after the consumption of a flavanol-rich cocoa. American Journal of Clinical Nutrition, 76(4): 798-804.
Ruggiero P, Tombola F, Rossi G, Pancotto L, Lauretti L, Del Giudice G, Zoratti M. 2006. Polyphenols reduce gastritis induced by Helicobacter pylori infection or Vac A toxin administration in mice. Antimicrob. Agents Chemother, 50(7): 2550-2552.

Scalbert A, Morand C, Manach C and Rémésy C. 2002. Absorption and metabolism of polyphenols in the gut and impact on health. Biomedicine Pharmarcotherapy, 56(6): 276-282.

Seigo B, Naomi O, Midori N Junji T. 2002. Absorption and urinary excretion of procyanidin B2 [epicatechin-(4ß-8)epicatechin] in rats. Free Radical Biology and Medicine, 33(1), 142-148.

Tapiero H, Tew KD, Ba GN, Mathe G. 2002. Polyphenols: do they play a role in the prevention of human pathologies? Biomed Pharmacother, 56: 200-207. 